Responsible Editor: Maria Dolores Sánchez-Fernández, Ph.D. Associate Editor: Manuel Portugal Ferreira, Ph.D.

Evaluation Process: Double Blind Review pelo SEER/OJS

\title{
A BIBLIOMETRIC ANALYSIS OF THE INTELLECTUAL STRUCTURE OF STUDIES ON SLAVERY IN THE 21ST CENTURY
}

\begin{abstract}
1Cíntia Cristina Silva de Araújo 2Erivaldo da Silva Carneiro Junior

\section{ABSTRACT}

Objective of the study: The aim of the article was to analyze the intellectual structure of publications on slavery within the scope of the Administration. To achieve this objective, the following research questions were proposed: What is the intellectual structure of recent publications on slavery in the business research area? How is the past of slavery remembered (or forgotten) in this century's researches on business research area?
\end{abstract}

Methodology/approach: We used the quantitative method of scientific mapping that combines bibliometrics and graphic representation. In this process, we extracted publications from the Scopus database and, then, grouped the references using the Bibexcel software. To identify the subgroups and create the visualization map, we used VOSviewer.

Originality/Relevance: Slavery is generally considered to be the dark side of business practices, and for this reason, it is a topic that is still little explored in management research. The relevance of this study is to systematize the academic production of this sensitive topic and to offer scholars and practitioners in the area a detailed analysis of the theoretical foundation of studies on slavery.

Main results: Results indicate that the intellectual structure of studies related to slavery can be grouped into nine pillars that cover several themes, such as heritage tourism, Critical Accounting, Management History and the perpetuation of the legacy of slavery in the globalized world.

Theoretical/methodological contributions (mandatory): Analyzing the repressed memory of slavery in the context of management is necessary and a great opportunity for future research. It is undeniable that slavery is a part of History that cannot be overlooked and this study explores this latent gap in Management studies.

Keywords: Slavery. Forced labor. Business history. Science Mapping. Bibliometric analysis. VOSviewer

Received on September 08th, 2019 Approved on November 19th, 2019

\section{(c) (i) (9)} (3) in 10

\section{How to Cite \\ (APA)}

Araújo, C., \& Carneiro Junior, E. (2020). A Bibliometric Analysis of the Intellectual Structure of Studies on Slavery in the 21st Century. International Journal of Professional Business Review (JPBReview), 5(1), 105-127. doi:http://dx.doi.org/10.26668/businessreview/2020.v5i1.175

\footnotetext{
${ }^{1}$ Universidade Nove de Julho - UNINOVE, São Paulo, (Brasil). E-mail: cintyaraujo@gmail.com Orcid id: https://orcid.org/0000-0001-8516-2479

${ }^{2}$ Instituição Financeira Banco do Brasil S.A. E-mail: erivaldo carneiro@yahoo.com.br Orcid id: https://orcid.org/0000-0002-6337-2819
} 


\section{UMA ANÁLISE BIBLIOMÉTRICA DA ESTRUTURA INTELECTUAL DOS ESTUDOS SOBRE A ESCRAVIDÃO NO SÉCULO 21}

\section{RESUMO}

Objetivo do estudo: O objetivo do artigo foi analisar a estrutura intelectual das publicações sobre escravidão no âmbito da Administração. Para atingir este objetivo, foram propostas as seguintes questões de pesquisa: Qual é a estrutura intelectual das publicações recentes sobre escravidão na área de pesquisa em negócios? Como o passado da escravidão é lembrado (ou esquecido) nas pesquisas deste século na área de pesquisa em negócios?

Metodologia/abordagem: Utilizamos o método quantitativo de mapeamento científico que combina bibliometria e representação gráfica. Neste processo, extraímos publicações do banco de dados Scopus e, em seguida, agrupamos as referências utilizando o software Bibexcel. Para identificar os subgrupos e criar o mapa de visualização, utilizamos o VOSviewer.

Originalidade/Relevância: A escravidão é geralmente considerada como o lado negro das práticas de negócios, e por este motivo, é um tema ainda pouco explorado em pesquisas da Administração. A relevância do presente estudo está em sistematizar a produção acadêmica deste tema sensível e em oferecer a estudiosos e praticantes da área uma análise detalhada do alicerce teórico de estudos sobre escravidão.

Principais resultados: Os resultados indicam que a estrutura intelectual dos estudos relacionados à escravidão pode ser agrupada em nove pilares que abrangem diversos temas, como turismo patrimonial, Contabilidade Crítica, História da Administração e a perpetuação do legado da escravidão no mundo globalizado.

Contribuições teóricas/metodológicas: Analisar a memória reprimida da escravidão no contexto da gestão é necessária e uma grande oportunidade para pesquisas futuras. É inegável que a escravidão é uma parte da história que não pode ser esquecida e este estudo explora esta lacuna latente nos estudos em Administração.

Palavras-chave: Escravidão. Trabalho forçado. História da Administração. Mapeamento científico. Análise bibliométrica. VOSviewer. 


\section{UN ANÁLISIS BIBLIOMÉTRICO DE LA ESTRUCTURA INTELECTUAL DE LOS ESTUDIOS SOBRE LA ESCLAVITUD EN EL SIGLO XXI}

\section{RESUMEN}

Objetivo del estudio: El objetivo del artículo fue analizar la estructura intelectual de las publicaciones sobre esclavitud en el ámbito de la Administración. Para lograr este objetivo, se propusieron las siguientes preguntas de investigación: ¿Cuál es la estructura intelectual de las publicaciones recientes sobre la esclavitud en el campo de la investigación empresarial? ¿Cómo se recuerda (u olvida) el pasado de la esclavitud en la investigación de este siglo en el campo de la investigación empresarial?

Metodología / enfoque: Utilizamos el método cuantitativo del mapeo científico que combina bibliometría y representación gráfica. En este proceso, extraemos publicaciones de la base de datos de Scopus y luego agrupamos las referencias utilizando el software Bibexcel. Para identificar los subgrupos y crear el mapa de visualización, usamos VOSviewer.

Originalidad/Relevancia: Generalmente, se considera que la esclavitud es el lado oscuro de las prácticas comerciales y, por esta razón, es un tema que todavía se explora poco en la investigación sobre Administración. La relevancia de este estudio es sistematizar la producción académica de este sensible tema y ofrecer a académicos y practicantes del área un análisis detallado del fundamento teórico de los estudios sobre la esclavitud.

Principales resultados: Los resultados indican que la estructura intelectual de los estudios relacionados con la esclavitud se puede agrupar en nueve pilares que abarcan varios temas, como el turismo patrimonial, la Contabilidad Crítica, la Historia de la Administración y la perpetuación del legado de la esclavitud en el mundo globalizado.

Contribuciones teóricas/metodológicas: Analizar la memoria reprimida de la esclavitud en el contexto de la gestión es necesario y una gran oportunidad para futuras investigaciones. Es innegable que la esclavitud es una parte de la historia que no puede pasarse por alto y este estudio explora esta brecha latente en los estudios de Administración.

Palabras llave: esclavitud; trabajo forzado; Historia de la Administración; mapeo científico . análisis bibliométrico; VOSviewer 


\section{INTRODUCTION}

Research on the slavery system, its residues and its contemporary forms fundamentally contributes to management and organization studies. Surely, studying problematic issues such as slavery and racism should be part of the research agenda for Latin American academics (Wanderley \& Barros, 2018). However, this theme has been neglected in management research, being usually regarded as the dark side of management and organizations (Godfrey, Hassard, O'Connor, Rowlinson, \& Ruef, 2016), resulting in the flagrant phenomenon known as the "denial of slavery in management studies" (Cooke, 2003, p. 1895).

Countering this tendency in the management area, scholars have argued that studies on slavery are necessary to integrate the concept of collective memory to organization studies, as well as to examine the idea of corporate responsibility regarding the past of slavery (Godfrey et al., 2016). Furthermore, slavery has lingered in modern business in different forms, from forced labor to human trafficking (Crane, 2013; Quirk, 2006). Slavery is still present, and its abolition, in "all of its forms", has been the goal of different international organizations, such as the United Nations (Weissbrodt, 2002, p. 5).

Therefore, we raise relevant questions for the area of business research area: What is the intellectual structure of recent publications on slavery in the business research area? How is the past of slavery remembered (or forgotten) in this century's researches on business research area?

To answer these questions, we conducted a study following the method of science mapping of slaveryrelated studies published from 2001 to 2019. Results allowed us to identify the theoretical pillars and the tendencies of researches regarding this intractable subject.

Following this introductory section, we present a brief literature review, followed by the research methodology, research results, discussion and our conclusions.

\section{LITERATURE REVIEW}

In the area of Organizational Studies, there is a poignant denial of slavery. Management history studies are based on events that occurred in ancient, premodern, and contemporary history. However, the slave period is excluded from analyzes and narratives about the evolution of management practices. The dark side of organizations is omitted, and thus, the narratives and memories about the complicity of organizations with slavery, wars and racism are omitted (Godfrey et al., 2016). For instance, in American studies on Business History, the history of management tends to ignore management and supervisory practices exercised during the American slavery period, although several studies show evidence that southern US plantations already used complex management practices- the American plantation overseers were the first salaried managers, a role very similar to the one played by the factory supervisors under the Taylorist-Fordist paradigm (Jones, Novicevic, Hayek, Humphreys, 2012).

\section{METHODOLOGY}

The methodology applied was science mapping, a quantitative method that, despite being considered recent, has been increasingly used to map and synthesize past publications in the management and organization fields (Nosella \& Cantarello, 2012; Shafique, 2013). Science mapping combines the use of a bibliometric map and a spatial representation. In fact, the use of bibliometric methods has been recommended as an alternative for systematic literature review and meta-analysis (Zupic \& Čater, 2015).

To be more objective and assertive, we followed the procedure recommended by Zupic \& Čater (2015), as illustrated in Figure 1.

After defining the research questions and goals, we opted for the bibliometric method of bibliographic coupling, since we aimed to examine the intellectual structure within a limited period 2001 to 2019 - and to identify emerging themes related to slavery. Besides that, recent publications have not accumulated citations yet, which requires the adoption of this bibliometric method. Then, we extracted publications from the Scopus database, within the business research area, using the following search keys: "slavery", "forced labor", "forced labour", "hard labor", "hard labour", "menial labor", and "menial labour". This preliminary search resulted in 372 publications, including books, articles and reviews. Afterwards, we cleaned the data, excluding works published before 2001, those without the name of the author, and duplicates. To ensure the 
accuracy of the number of citations, we grouped the references of the 324 remaining publications, using the bibliometric software Bibexcel (Quevedo-Silva, Santos, Brandão, \& Vils, 2016).
After conducting these steps, we realized that publications on slavery or related themes have increased in recent years; from the 324 publications, 164 (50.61\%) were published after 2014.

Figure 1: Research design

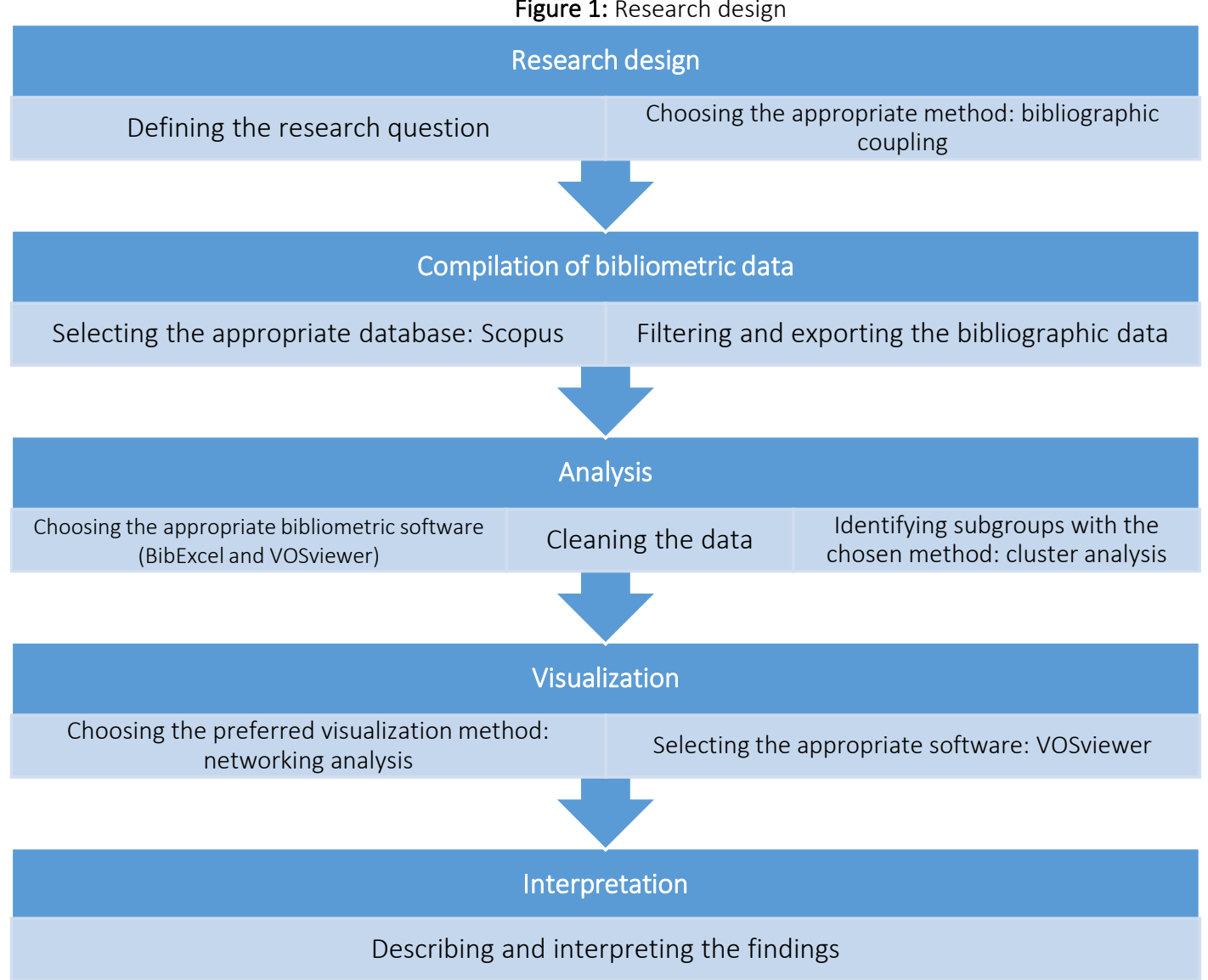

Source: Based on Zupic \& Čater (2015)

After adjustments, we used the software Vosviewer to identify the subgroups with the dimension reduction technique of cluster analysis and to create the visualization map. As we created this map on VOSviewer, we included publications with at least five citations. To normalize the differences between the nodes, the software uses the association strength normalization, which is based on the strength of the links between the nodes. After normalization, we identified that within 324 publications, 89 publications shared references.

\section{RESULTS}

\section{Network visualization and findings from the cluster analysis}

The network map created by VOSviewer presents the analyzed publications as nodes, whereas the links between the nodes represent the similarity between these nodes (documents). As the software uses the distance-based approach, the distance between the nodes indicates their relatedness (Van Eck \& Waltman, 2014). Moreover, the bigger the node, the bigger the number of documents that share the same references is.

As we see the network visualization in Figure

2, the software identified nine subgroups (clusters). 


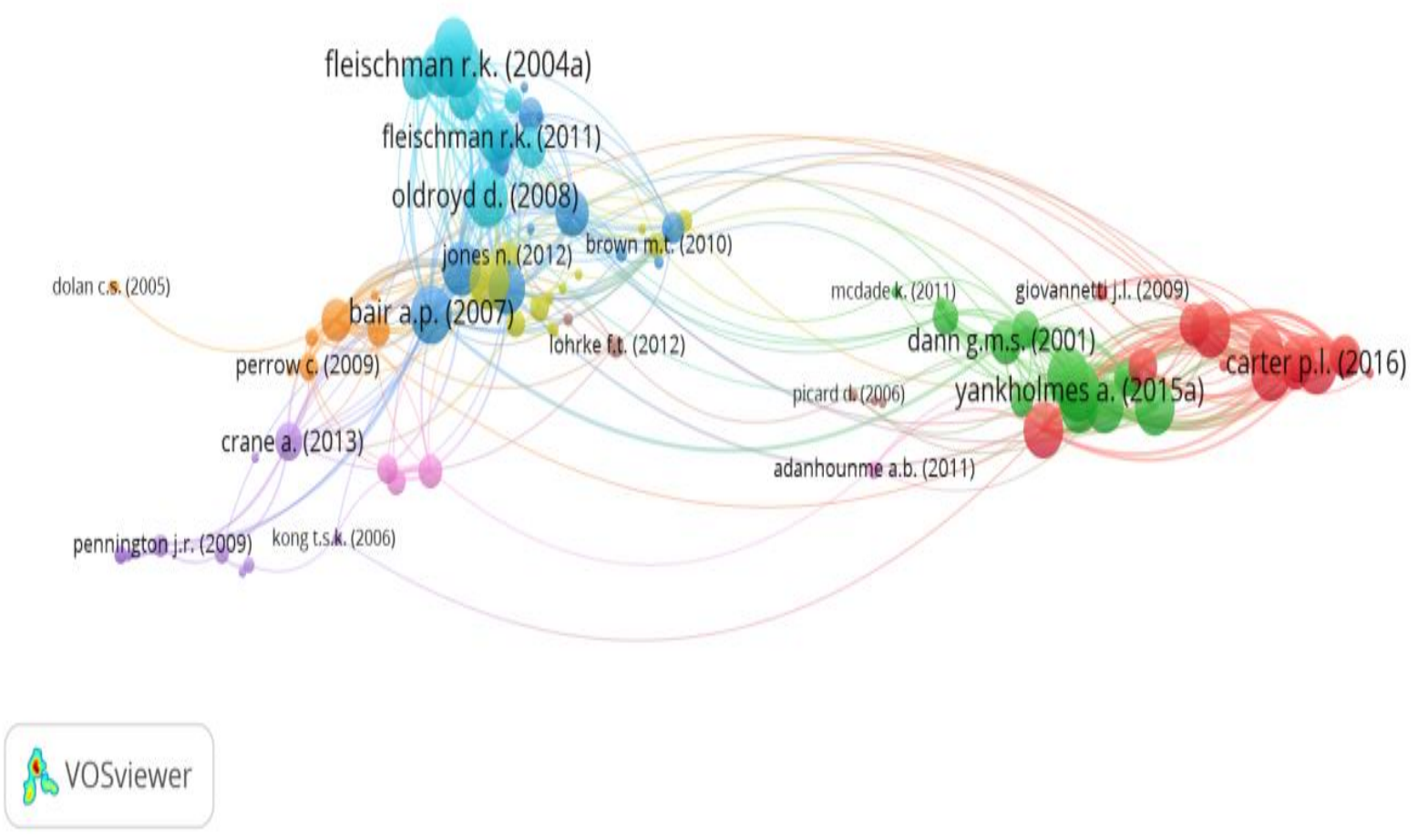

Figure 2: Network map based on cluster analysis Source: Authors

The network map shows that nodes of clusters 3 , $6,7,9,5$, and 4 are close to each other on the left side of the map, while clusters 1,2 , and 8 are grouped on the other side. This design indicates that the nodes are more related to each other, which can be confirmed as we observe the themes and references they share.

Table 1 presents the main features of the publications included in the nine clusters.

Following, we present an analysis of the nine clusters.

\section{Cluster 1: Conflicting narratives of slavery in heritage tourism}

This cluster comprises 14 of the 89 studies of the network: thirteen articles and one book chapter. The central theme is the narrative of former plantations currently being used for tourist purposes. Most articles focus on heritage tourism in the United States; only one of them focuses on heritage sites outside the United States (Giovannetti, 2009). The use of gloomy historical sites for tourist purposes was discussed when concentration camps became memorials (Beech, 2000). As these 14 articles show, the implementation of museums and tourist exhibitions on former plantations in southern United States has grown, and researchers have identified a conflict between the narratives produced on tourist sites and the real history of slaves and slave owners. For Hanna (2015), the way exhibitions and museums are organized can misrepresent the scenario of forced labor in plantations and dehumanize the people who suffered with the slavery system. Plantation owners and tour guides might present narratives that can trivialize the practices that occurred in these plantations in antebellum US (Alderman \& Gentry, 2011). Authors also criticize historians' and docents' absence of engagement in offering a didactic and critical narrative that allows visitors to ponder on the impact of slavery today.

\section{Cluster 2: Slavery, heritage tourism and collective memory}

This cluster contains 14 articles. Except for Mcdade (2011), cluster 2 mostly discusses slavery heritage, similarly to cluster 1 . In fact, some studies 
also criticize how exhibitions or tour guides can overlook the long-term impact of slavery (Beech, 2001). Nonetheless, cluster 2 includes more articles addressing heritage tourism in other countries besides the US. Another significant difference is that in cluster 2 we find articles that analyze the role of slavery heritage from the perspective of collective memory: how the narrative adopted in a heritage tourist site can impact the way society will remember or forget historical events. Therefore, several of them deal with aspects such as reconciliation, collective memory, and nostalgia (Buzinde \& Santos, 2008; Teye \& Timothy, 2004). It is worth noting the discussion of Eurocentric narratives that whitewashes multicultural inherited societies (Frost, 2004) and the element of dissonant heritage in which different groups tell different stories about the same object or event (Yankholmes \& Mckercher, 2015a). 
Table 1. The main features of the publications included in the nine clusters

\begin{tabular}{|c|c|c|c|c|}
\hline Authors & Main Objective & Reference Theory & Context $\left({ }^{1}\right)$ & Cit. $\left({ }^{2}\right)$ \\
\hline $\begin{array}{l}\text { Alderman and Gentry } \\
\qquad(2011)\end{array}$ & $\begin{array}{l}\text { Applying the concept of affect: the narratives about the enslaved are } \\
\text { less emotive than the ones about the slave owners }\end{array}$ & Affective inequality & $\begin{array}{l}\text { Docent-led tour guides in } \\
\text { Destrehan } \\
\text { Louisiana }\end{array}$ & 108 \\
\hline $\begin{array}{l}\text { Alderman and Modlin } \\
\text { (2015) }\end{array}$ & $\begin{array}{l}\text { Understanding how visitors at plantation museums can help build } \\
\text { and shape the meaning and the impact of the narrative }\end{array}$ & Memory & $\begin{array}{l}\text { Museums of Louisiana's } \\
\text { River Road plantations }\end{array}$ & 15 \\
\hline $\begin{array}{l}\text { Alderman, Butler, and } \\
\text { Hanna (2015) }\end{array}$ & $\begin{array}{l}\text { Presenting the special issue of the Journal of Heritage Tourism that } \\
\text { focuses on the River Road project }\end{array}$ & Memory, Legacy & $\begin{array}{l}\text { River Road Project } \\
\text { (Louisiana) }\end{array}$ & 26 \\
\hline $\begin{array}{l}\text { Alderman and Modlin } \\
\qquad(2008)\end{array}$ & $\begin{array}{l}\text { Measuring the degree to which the history of slavery and the } \\
\text { enslaved are disclosed in the marketing texts of plantation websites }\end{array}$ & $\begin{array}{l}\text { Marginalization of the } \\
\text { enslaved, Romanticism of } \\
\text { narratives }\end{array}$ & $\begin{array}{l}\text { Tourist plantations in North } \\
\text { Carolina }\end{array}$ & 63 \\
\hline Bright and Butler (2015) & $\begin{array}{l}\text { Analyzing the evolution of the narratives presented in plantation } \\
\text { tourism websites }\end{array}$ & $\begin{array}{l}\text { Whitewashing, } \\
\text { Trivialization }\end{array}$ & Tourist plantations & 7 \\
\hline Buzinde and Santos (2009) & Understanding visitors' perceptions on former slave plantations & Perception, Ideology & $\begin{array}{l}\text { Hampton Plantation Historic } \\
\text { Site and surrounding area }\end{array}$ & 95 \\
\hline Buzinde (2010) & $\begin{array}{l}\text { Analyzing the construction of the collective memory in former slave } \\
\text { plantations }\end{array}$ & Collective memory & $\begin{array}{l}\begin{array}{l}\text { Tourist plantations in } \\
\text { Louisiana }\end{array} \\
\end{array}$ & 13 \\
\hline Carter (2016) & $\begin{array}{l}\text { Analyzing what visitors absorb and perceive from tours in plantation } \\
\text { museums }\end{array}$ & $\begin{array}{l}\text { Narrative agents, } \\
\text { Marginalization, } \\
\text { Romanticism }\end{array}$ & $\begin{array}{l}\text { Laura and Oak Alley } \\
\text { plantation museums }\end{array}$ & 24 \\
\hline $\begin{array}{l}\text { Dwyer, Butler, and Carter } \\
\text { (2013) }\end{array}$ & $\begin{array}{l}\text { Understanding visitors' reaction to the narratives and to historical } \\
\text { objects in plantation and civil rights museums }\end{array}$ & Surrogation & $\begin{array}{l}\text { Southern plantation and civil } \\
\text { rights museums }\end{array}$ & 43 \\
\hline Giovannetti (2009) & $\begin{array}{l}\text { Analyzing the politics behind the representation of slavery in } \\
\text { plantation tourist sites in Caribbean and South America }\end{array}$ & $\begin{array}{l}\text { Narrative agents, Teaching } \\
\text { as a narrative builder }\end{array}$ & $\begin{array}{l}\text { Plantation sites in Puerto } \\
\text { Rico, Cuba, Barbados and } \\
\text { Brazil }\end{array}$ & 14 \\
\hline Hanna (2015) & $\begin{array}{l}\text { Understanding how difficult it is to include the real history of slavery } \\
\text { in the narratives produced by plantation museums }\end{array}$ & $\begin{array}{l}\text { Annihilation, } \\
\text { Whitewashing, Surrogation }\end{array}$ & $\begin{array}{l}\text { The exhibition "Slavery at the } \\
\text { Oak Alley", in Louisiana }\end{array}$ & 18 \\
\hline Litvin \& Brewer (2016) & $\begin{array}{l}\text { Criticizing the narratives about slavery presented in plantation } \\
\text { museums and historic heritage sites }\end{array}$ & Memory, Whitewashing & $\begin{array}{l}\text { Tourist plantations in } \\
\text { Charleston, South Carolina }\end{array}$ & 10 \\
\hline
\end{tabular}

\footnotetext{
${ }^{1}$ industry sector, country, region, period in history

2 number of citations according to Google Scholar - updated on January, 8th, 2020
} 


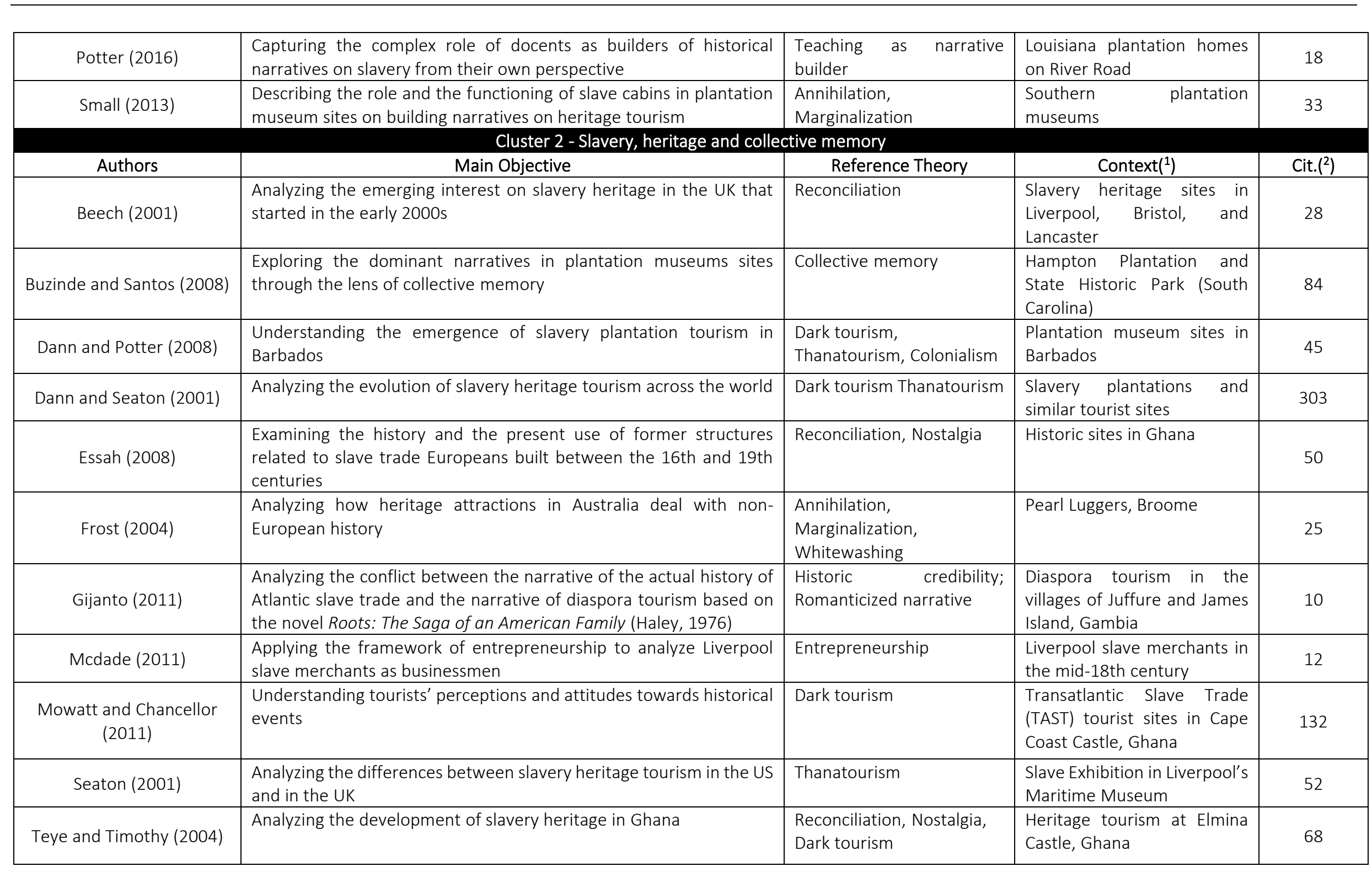




\begin{tabular}{|c|c|c|c|c|}
\hline $\begin{array}{l}\text { Yankholmes and } \\
\text { Mckercher (2015b) }\end{array}$ & $\begin{array}{l}\text { Identifying and categorizing visitors of TAST tourist sites based on } \\
\text { their knowledge, attitudes, motives, and sensitivity to the historical } \\
\text { past of these places }\end{array}$ & $\begin{array}{l}\text { Sensitivity, Reconciliation, } \\
\text { Collective memory }\end{array}$ & TAST tourist sites in Ghana & 37 \\
\hline $\begin{array}{l}\text { Yankholmes and } \\
\text { Mckercher (2015a) }\end{array}$ & $\begin{array}{l}\text { Analyzing slavery heritage through the lens of collective memory and } \\
\text { dissonant heritage }\end{array}$ & $\begin{array}{ll}\text { Collective } & \text { memory, } \\
\text { Dissonant } & \text { heritage, } \\
\text { Narrative agents } & \\
\end{array}$ & TAST tourist sites in Osu & 21 \\
\hline $\begin{array}{c}\text { Yankholmes and } \\
\text { Akyeampong (2010) }\end{array}$ & $\begin{array}{l}\text { Identifying tourists' perceptions and attitudes and exploring the } \\
\text { ethical issues of heritage tourism }\end{array}$ & Dark tourism, Nostalgia & TAST tourist sites in Osu & 64 \\
\hline \multicolumn{5}{|c|}{ Cluster 3 - Slavery and the history of Social Sciences and Humanities } \\
\hline Authors & Main Objective & Reference Theory & Context $\left({ }^{1}\right)$ & Cit. $\left({ }^{2}\right)$ \\
\hline Bair (2007) & $\begin{array}{l}\text { Conducting a systematic analysis of contemporary prison labor in the } \\
\text { US }\end{array}$ & $\begin{array}{l}\text { Prison labor as a form of } \\
\text { forced labor, Racial } \\
\text { segregation }\end{array}$ & Prison labor in the US & 15 \\
\hline Cooke (2003) & $\begin{array}{l}\text { Demonstrating the relevance of slavery in the study of management } \\
\text { history }\end{array}$ & $\begin{array}{ll}\text { Management } & \text { history, } \\
\text { Capitalism } & \end{array}$ & $\begin{array}{l}\text { The manager figure in } \\
\text { management history }\end{array}$ & 240 \\
\hline Cremaschi (2014) & $\begin{array}{l}\text { Reconstructing Malthus' moral, normative, and applied ethics } \\
\text { regarding population, poverty, sexuality, war, and slavery }\end{array}$ & $\begin{array}{l}\text { Malthusianism, } \\
\text { Utilitarianism }\end{array}$ & $\begin{array}{l}\text { Economic and philosophical } \\
\text { ethics of the 18th century }\end{array}$ & 24 \\
\hline de la Fuente (2010) & $\begin{array}{l}\text { Understanding why Tannenbaum continues to influence the work of } \\
\text { modern researchers of race relations and slavery }\end{array}$ & Colonialism & Anglo and Latin countries & 28 \\
\hline DuPlessis (2016) & $\begin{array}{l}\text { Examining the global textile commerce in the Atlantic World, which } \\
\text { changed consumer behavior and created new economies and } \\
\text { societies during the 18th century }\end{array}$ & $\begin{array}{l}\text { Colonialism, } \quad \text { Capitalism, } \\
\text { Economics }\end{array}$ & $\begin{array}{l}\text { Colonialism and economics } \\
\text { history }\end{array}$ & 48 \\
\hline Engerman (2011) & $\begin{array}{l}\text { Analyzing the concept of freedom that argues that the ability to } \\
\text { make choices is a fundamental element in economy }\end{array}$ & $\begin{array}{l}\text { Freedom, Feminist view on } \\
\text { capitalism }\end{array}$ & Antebellum South (US) & 38 \\
\hline Gaido (2006) & $\begin{array}{l}\text { Analyzing the development of American capitalism through the lens } \\
\text { of Marxism }\end{array}$ & $\begin{array}{l}\text { Historical materialism, } \\
\text { Marxism, Imperialism }\end{array}$ & $\begin{array}{l}\begin{array}{l}\text { History of American } \\
\text { capitalism }\end{array} \\
\end{array}$ & 13 \\
\hline Goldin (2016) & $\begin{array}{l}\text { Discussing the historical perspective of the concept of human capital } \\
\text { focusing on two components: education/training and health }\end{array}$ & $\begin{array}{l}\text { Human capital, Population } \\
\text { theory }\end{array}$ & $\begin{array}{l}\text { Human capital and } \\
\text { population development } \\
\text { between the 18th and the } \\
\text { 20th centuries }\end{array}$ & 129 \\
\hline Phillips (2013) & $\begin{array}{l}\text { Providing a thorough analysis of the slavery system in the Iberian } \\
\text { Peninsula from ancient times to the decline of slavery in the 18th } \\
\text { century, including the examination of legal terms of the slavery } \\
\text { system, from purchase to manumission }\end{array}$ & Law system of slavery & $\begin{array}{l}\text { Slavery in the Iberian } \\
\text { Peninsula }\end{array}$ & 77 \\
\hline
\end{tabular}




\begin{tabular}{|c|c|c|c|c|}
\hline Schermerhorn (2015) & $\begin{array}{l}\text { Presenting a historical analysis of the development of modern } \\
\text { American capitalism through the lens of 18th-century slave trade }\end{array}$ & $\begin{array}{l}\text { History of capitalism, } \\
\text { Economics history }\end{array}$ & Economy in antebellum US & 68 \\
\hline Authors & Main Objective & Reference Theory & Context $\left({ }^{1}\right)$ & Cit. $\left({ }^{2}\right)$ \\
\hline Brown (2010) & Criticizing Adam Smith's concept of property & Economic Theory & World economic system & 50 \\
\hline Dahan and Gittens (2010) & $\begin{array}{l}\text { Arguing that ethical public decision-making may not be based on a } \\
\text { single actor (managers, organizations) but on many different key } \\
\text { stakeholders }\end{array}$ & $\begin{array}{l}\text { Sociological theory of issue } \\
\text { framing }\end{array}$ & Cocoa industry in West Africa & 23 \\
\hline Hayek et al. (2010) & $\begin{array}{l}\text { Analyzing the period of slavery by focusing on the phenomenon of } \\
\text { paternalistic leadership by Joseph E. Davis during slavery in the US }\end{array}$ & Leadership Theory & $\begin{array}{l}\text { Antebellum period of slavery } \\
\text { in the US }\end{array}$ & 33 \\
\hline Jones et al. (2012) & $\begin{array}{l}\text { Establishing and tracing the roots of African-American management } \\
\text { by examining managerial practices and experiences of an } \\
\text { emancipated former slave who eventually became a plantation } \\
\text { manager and owner }\end{array}$ & Leadership Theory & $\begin{array}{l}\text { Slavery in the US during the } \\
1865-1870 \text { period }\end{array}$ & 11 \\
\hline Ma et al. (2015) & $\begin{array}{l}\text { Assessing the results of initiatives to abolish slavery and human } \\
\text { trafficking from supply chain in manufacturing and retail after the } \\
\text { legislation of the California Transparency in Supply Chains Act } \\
\text { (CTSCA) }\end{array}$ & $\begin{array}{l}\text { Human trafficking, SCM, } \\
\text { Forced labor }\end{array}$ & $\begin{array}{l}\text { Apparel retail and apparel } \\
\text { manufacturing companies } \\
\text { based in the US }\end{array}$ & 14 \\
\hline
\end{tabular}




\begin{tabular}{|c|c|c|c|c|}
\hline $\begin{array}{l}\text { Magnan, Fawcett, and } \\
\text { Alcantar (2011) }\end{array}$ & $\begin{array}{l}\text { Analyzing the maturity of conduct codes from apparel, retail and } \\
\text { other manufacturing businesses }\end{array}$ & \begin{tabular}{ll|} 
Corporate & social \\
responsibility (CSR), SCM, \\
Reputation risk
\end{tabular} & Apparel and retail business & 18 \\
\hline New (2015) & $\begin{array}{l}\text { Examining modern slavery in the supply chain and how this practice } \\
\text { challenges the conventional thinking and practice of corporate social } \\
\text { responsibility }\end{array}$ & CSR, SCM & UK agriculture & 64 \\
\hline Osterhammel (2014) & $\begin{array}{l}\text { Analyzing the different (complex and powerful) forces that } \\
\text { influenced the transformations during the 19th century }\end{array}$ & Economics history & $\begin{array}{l}\text { Economic and political } \\
\text { changes in the 19th century }\end{array}$ & 572 \\
\hline Robinson (2002) & $\begin{array}{l}\text { Identifying patterns of gender and } \\
\text { familial-status discrimination }\end{array}$ & \begin{tabular}{ll|}
$\begin{array}{l}\text { Racism, } \\
\text { discrimination }\end{array}$ & Gender \\
\end{tabular} & $\begin{array}{l}\text { Mortgage lending market in } \\
\text { the US }\end{array}$ & 30 \\
\hline Winter and Lasch (2016) & $\begin{array}{l}\text { Examining how companies apply environmental and social criteria in } \\
\text { supplier evaluation }\end{array}$ & CSR & Fashion and apparel industry & 60 \\
\hline \multicolumn{5}{|c|}{ Cluster 5 - The legacy of slavery in social issues of today's globalized world } \\
\hline Authors & Main Objective & Reference Theory & Context $\left({ }^{1}\right)$ & Cit. $\left({ }^{2}\right)$ \\
\hline Burity (2008) & $\begin{array}{l}\text { Arguing that globalization can give rise to economic powers that can } \\
\text { either reinforce or revert historical social inequalities }\end{array}$ & $\begin{array}{l}\text { Imperialism, Colonialism, } \\
\text { Capitalism }\end{array}$ & $\begin{array}{l}\text { The effects of globalization in } \\
\text { Brazil }\end{array}$ & 17 \\
\hline Busse and Braun (2003) & $\begin{array}{l}\text { Assessing the extent of forced labor in different countries and how } \\
\text { forced labor affects foreign direct investment (FDI) }\end{array}$ & $\begin{array}{l}\text { Contemporary forms of } \\
\text { forced labor }\end{array}$ & $\begin{array}{l}\text { Labor standards on exports } \\
\text { of unskilled-labor-intensive } \\
\text { goods }\end{array}$ & 63 \\
\hline $\begin{array}{l}\text { Campo, Mastin, and Frazer } \\
(2004)\end{array}$ & $\begin{array}{l}\text { Assessing public opinion regarding slavery reparations and forms of } \\
\text { compensation }\end{array}$ & $\begin{array}{l}\text { Historical reparation and } \\
\text { compensation }\end{array}$ & $\begin{array}{l}\text { State university in southern } \\
\text { US }\end{array}$ & 16 \\
\hline Crane (2013) & $\begin{array}{l}\text { Demonstrating that slavery is a management practice due to factors } \\
\text { that make it an institutional and competitive practice, and because } \\
\text { organizations can isolate themselves from external pressures }\end{array}$ & $\begin{array}{l}\text { Legitimacy, Institutional } \\
\text { theory }\end{array}$ & $\begin{array}{l}\text { Modern slavery as a } \\
\text { management practice }\end{array}$ & 201 \\
\hline Duplessis (2004) & $\begin{array}{l}\text { Examining the efficiency of the International Labor Organization } \\
\text { (ILO) Declaration on Fundamental Principles and Rights at Work on } \\
\text { dealing with the challenges of globalization }\end{array}$ & $\begin{array}{l}\text { Globalization, Institutional } \\
\text { theory, Labor rights }\end{array}$ & $\begin{array}{l}\text { Rights at work in a globalized } \\
\text { economy }\end{array}$ & 29 \\
\hline $\begin{array}{l}\text { Giusta, Tommaso, and } \\
\text { Strøm (2008) }\end{array}$ & $\begin{array}{l}\text { Developing a theoretical model for the commercial sex industry } \\
\text { based on data collected from a database of trafficked women }\end{array}$ & \begin{tabular}{lr|} 
Reputation $\quad$ cost, \\
Prostitution, $\quad$ Human \\
trafficking, Sex slavery
\end{tabular} & $\begin{array}{l}\text { Sex market in developed } \\
\text { countries }\end{array}$ & 37 \\
\hline $\begin{array}{l}\text { Jakobsson and Kotsadam } \\
\qquad(2013)\end{array}$ & $\begin{array}{l}\text { Showing that human trafficking for commercial sex is more frequent } \\
\text { in countries where prostitution is legalized than in countries where } \\
\text { it is illegal }\end{array}$ & $\begin{array}{l}\text { Human trafficking, Labor } \\
\text { rights, Sex slavery }\end{array}$ & $\begin{array}{l}\text { Human trafficking for } \\
\text { commercial sex in Europe }\end{array}$ & 178 \\
\hline Kong (2006) & $\begin{array}{l}\text { Investigating the complexity of female prostitutes' reality in Hong } \\
\text { Kong using the oral history method }\end{array}$ & Forced labor, Body politics & Erotic labor in Hong Kong & 99 \\
\hline
\end{tabular}




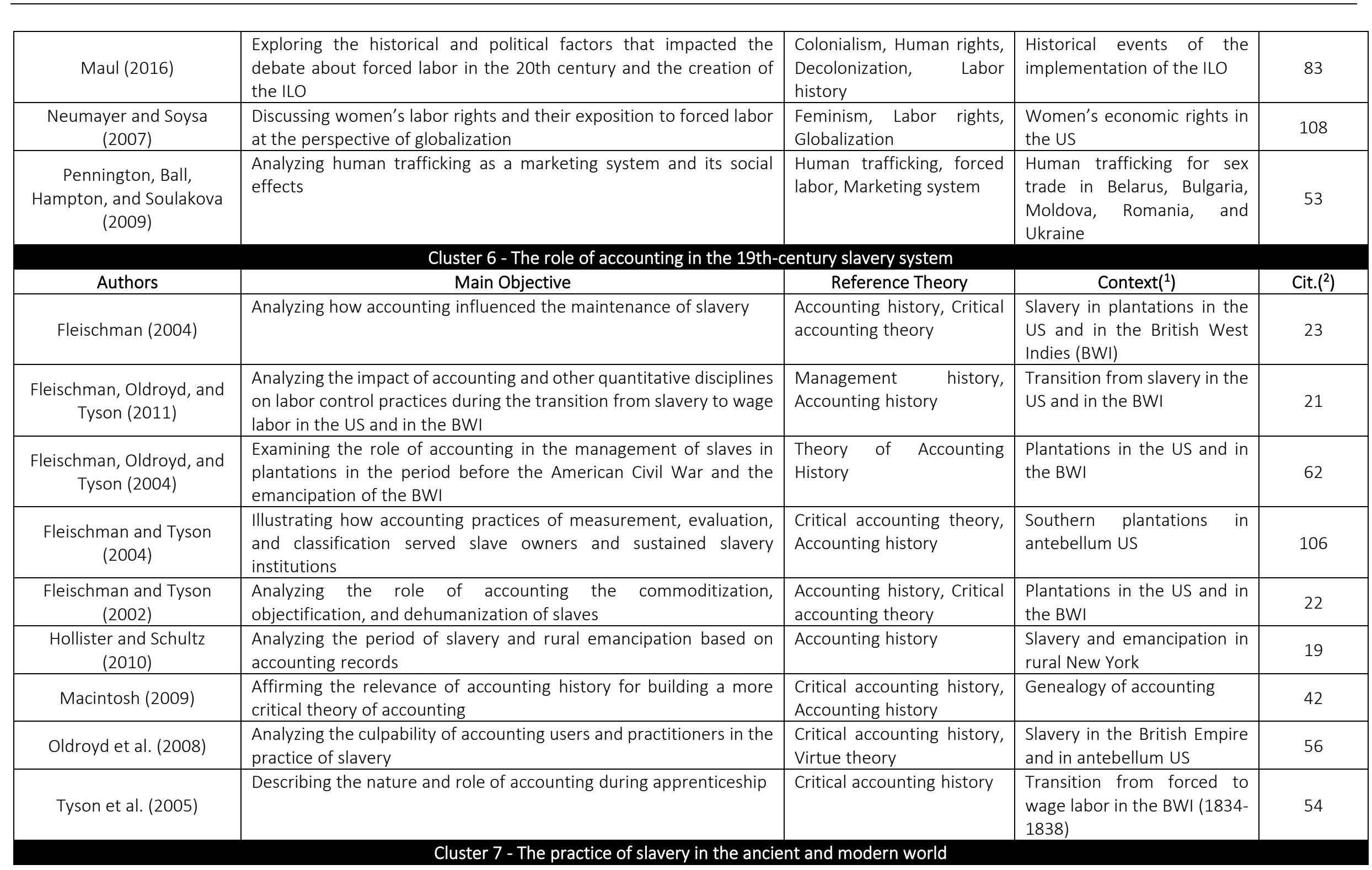




\begin{tabular}{|c|c|c|c|c|}
\hline Authors & Main Objective & Reference Theory & Context $\left({ }^{1}\right)$ & Cit. $\left({ }^{2}\right)$ \\
\hline Anner (2007) & $\begin{array}{l}\text { Analyzing the evolution of labor union and labor actions in El } \\
\text { Salvador and Brazil }\end{array}$ & Unions, Labor history & $\begin{array}{l}\text { Salvadoran export apparel } \\
\text { industry and Brazilian } \\
\text { automobile industry }\end{array}$ & 22 \\
\hline Barlev (2006) & $\begin{array}{l}\text { Analyzing the Biblical statement of accountability presented by } \\
\text { Moses to the Israelites in the exodus from Egypt }\end{array}$ & $\begin{array}{l}\text { Leadership theory, } \\
\text { Accounting history }\end{array}$ & $\begin{array}{l}\text { Period of the Exodus (1200 } \\
\mathrm{BC} \text { ) }\end{array}$ & 23 \\
\hline Dolan (2005) & $\begin{array}{l}\text { Examining ethical views of British consumers and retailers towards } \\
\text { Kenya's luxury vegetable trade and the narratives inherited from } \\
\text { 19th-century colonialism }\end{array}$ & \begin{tabular}{lc|} 
Consumer & behavior, \\
Colonialism, Imperialism
\end{tabular} & $\begin{array}{l}\text { Consumption of African } \\
\text { vegetables in the UK }\end{array}$ & 68 \\
\hline Freedman (2008) & $\begin{array}{l}\text { Discussing the Chicago School's views on economy and their position } \\
\text { against the Keynesian thought }\end{array}$ & Liberal economic theory & $\begin{array}{l}\text { Chicago counterrevolution } \\
\text { school }\end{array}$ & 33 \\
\hline Godfrey (2016) & $\begin{array}{l}\text { Emphasizing the importance of organizational history in organization } \\
\text { studies }\end{array}$ & Organization history & Organization studies & 64 \\
\hline Perrow (2009) & $\begin{array}{l}\text { Analyzing the development of American society through the } \\
\text { development of corporate capitalism }\end{array}$ & $\begin{array}{lr}\text { Economics } & \text { theory, } \\
\text { Institutional } & \text { theory, Power } \\
\text { relations, History of } \\
\text { capitalism, } \\
\text { capitalism }\end{array}$ & American corporate society & 598 \\
\hline Rodet (2014) & $\begin{array}{l}\text { Analyzing the impact of French colonization in the practice of forced } \\
\text { labor through the lens of gender standards }\end{array}$ & $\begin{array}{l}\text { Gender perspective, Labor } \\
\text { rights, Colonialism }\end{array}$ & $\begin{array}{l}\text { French colonization in Sudan } \\
(1919-1946)\end{array}$ & 3 \\
\hline Ruef and Harness (2009) & $\begin{array}{l}\text { Analyzing management practices in the slavery system of agrarian } \\
\text { Roman Republic and antebellum US }\end{array}$ & \begin{tabular}{lr|} 
Agency & Theory, \\
Management $\quad$ theory, \\
Management history
\end{tabular} & $\begin{array}{l}\text { Slavery system in the Roman } \\
\text { Republic and antebellum US }\end{array}$ & 19 \\
\hline Authors & $\begin{array}{l}\text { Cluster } 8 \text { - Rupturing relations with the dark side of his } \\
\text { Main Objective }\end{array}$ & $\begin{array}{l}\text { and dealing with its vestig } \\
\text { Reference Theory }\end{array}$ & Context $\left({ }^{1}\right)$ & Cit. $\left({ }^{2}\right)$ \\
\hline (Brown, 2013) & $\begin{array}{l}\text { Analyzing the role of museum shops in dark tourist sites and the } \\
\text { conflicting ideology of selling products in these locations }\end{array}$ & Dark tourism & $\begin{array}{l}\text { Museum shops in dark } \\
\text { tourist sites }\end{array}$ & 35 \\
\hline $\begin{array}{l}\text { (Lohrke, Ahlstrom, \& } \\
\quad \text { Bruton, 2012) }\end{array}$ & $\begin{array}{l}\text { Analyzing turnaround strategies by understanding the history of } \\
\text { organization turnaround employed by the US government during the } \\
\text { Civil War }\end{array}$ & $\begin{array}{l}\text { Turnaround management, } \\
\text { Strategic management }\end{array}$ & $\begin{array}{l}\text { Organizational turnaround of } \\
\text { the US government during } \\
\text { the Civil War }\end{array}$ & 14 \\
\hline (Lynch \& Alberti, 2010) & $\begin{array}{l}\text { Analyzing the vestiges of institutional racism in race-related cultural } \\
\text { exhibitions }\end{array}$ & Institutional racism & $\begin{array}{l}\text { "Revealing Histories: Myths } \\
\text { about Race" exhibition at the } \\
\text { Manchester Museum, UK }\end{array}$ & 168 \\
\hline (Mittal \& Weingast, 2011) & $\begin{array}{l}\text { Developing and applying the theory of self-enforcing constitutions to } \\
\text { the reality of early US }\end{array}$ & $\begin{array}{l}\text { Theory of self-enforcing } \\
\text { constitutions, } \\
\text { Constitutional democracy }\end{array}$ & Slavery in the US & 83 \\
\hline
\end{tabular}




\begin{tabular}{|c|c|c|c|c|}
\hline (Picard, 2006) & $\begin{array}{l}\text { Analyzing festival boom as symbolism of rupture and transition in } \\
\text { international tourism }\end{array}$ & $\begin{array}{l}\text { International tourism, Life } \\
\text { crisis, Symbolism }\end{array}$ & $\begin{array}{l}\text { The Abolition of Slavery Day } \\
\text { Festival, in La Réunion }\end{array}$ & 8 \\
\hline \multicolumn{5}{|c|}{ Cluster 9 - Corporate culture as a form of domination } \\
\hline Authors & Main Objective & Reference Theory & Context $\left({ }^{1}\right)$ & Cit. $\left({ }^{2}\right)$ \\
\hline Adanhounme (2011) & $\begin{array}{l}\text { Exploring the extent to which CSR in African organizations } \\
\text { reproduces the colonialism that imposed Western mandate over } \\
\text { local communities }\end{array}$ & $\begin{array}{l}\text { Corporate } \\
\text { responsibility, } \\
\text { Postcolonialism, } \\
\text { Colonialism, } \\
\text { Marginalization }\end{array}$ & Mining plant in Ghana & 36 \\
\hline Fleming (2013) & $\begin{array}{l}\text { Discussing the totalitarian aspiration of corporate culturalism by } \\
\text { comparing the works of Willmott (1993) and Orwell (2011) }\end{array}$ & $\begin{array}{ll}\begin{array}{l}\text { Organization } \\
\text { Corporate }\end{array} & \begin{array}{l}\text { culture, } \\
\text { culture, } \\
\text { Totalitarianism }\end{array} \\
\end{array}$ & $\begin{array}{l}\text { Corporate culture in } \\
\text { contemporary management }\end{array}$ & 56 \\
\hline Willmott (2003) & $\begin{array}{l}\text { Revisiting Willmott's (1993) idea of totalitarianism in corporate } \\
\text { culture and its relevance to contemporary and "post-bureaucracy" } \\
\text { management }\end{array}$ & $\begin{array}{lr}\text { Corporate } & \text { culture, } \\
\text { Organization } & \text { culture, } \\
\text { Corporate } & \text { culturalism, } \\
\text { Totalitarianism } & \end{array}$ & $\begin{array}{l}\text { Corporate culture in } \\
\text { contemporary management, } \\
\text { post-bureaucracy era }\end{array}$ & 48 \\
\hline Willmott (2013) & $\begin{array}{l}\text { Revisiting Willmott's (1993) idea of totalitarianism in corporate } \\
\text { culture and its relevance to contemporary management and } \\
\text { organization studies, as well as to higher education }\end{array}$ & $\begin{array}{lr}\text { Corporate } & \text { culture, } \\
\text { Organization } & \text { culture, } \\
\text { Corporate } & \text { culturalism, } \\
\text { Normative control } & \end{array}$ & $\begin{array}{l}\text { Corporate culture in } \\
\text { contemporary management }\end{array}$ & 27 \\
\hline
\end{tabular}

Source: Authors

\footnotetext{
1 industry sector, country, region, period in history

2 number of citations according to Google Scholar - updated on January, 8th, 2020
} 


\section{Cluster 3: Slavery and the history of Social Sciences and Humanities}

This cluster includes five articles, seven books and one book chapter. Several of these publications address the role of slavery in the history of the main areas of Social Sciences and Humanities (Economics, Law, Management, Sociology). The book by DuPlessis (2016), for instance, discusses how the 18th-century global textile trade imposed European clothing standards upon Africans and natives. (Armstrong, 2018)) examines the global textile commerce in the Atlantic World, which changed consumer behavior and created new economies and societies during the 18th century (DuPlessis, 2016).

Regarding the history of capitalism, there are interesting empirical studies that discuss the role and the legacy of slavery in race and class relations (Ruef, 2014), as well as the transition from agrarian to industrial capitalism (Schermerhorn, 2015).

Finally, studies analyze management practices used to control slaves in industries (Vollmers, 2003) and the inexplicable exclusion of slavery from management history (Cooke, 2003). The area of marketing is also analyzed, as Podoshen (2012) studies consumer behavior of non-African and African-Americans towards companies that once had any relationship to the slavery system.

\section{Cluster 4: Contemporary slavery and other residues of slavery in modern management practices}

This cluster comprises nine articles and two books, with themes ranging from the leadership exercised by plantation owners who enslaved blacks from Africa in the US (Hayek, Novicevic, Humphreys, \& Jones, 2010) to current issues such as modern slavery in the supply chain (Gold, Trautrims, \& Trodd, 2015). Aspects such as sustainability, corporate social responsibility, image risk, ethics and integrity are also present, indicating that discussions which combat slavery are present today. In fact, some studies analyze the impact of the implementation of the California Transparency in Supply Chains Act (CTSCA) as an initiative to abolish forced labor and human trafficking (Ma, Lee, \& Goerlitz, 2015). We also found discussions on the different Economics schools (Chicago School and Keynesianism) and how they oppose Adam Smith's concept of capital accumulation (Brown, 2010).

\section{Cluster 5: The legacy of slavery in social issues of today's globalized world}

The fifth cluster contains ten articles and one book. The articles in this group discuss the legacy of slavery at different levels of today's society and how it is being dealt with or even overlooked. First, we find studies on the new forms of slavery and forced labor. Published in the renowned Academy of Management Review, Crane (2013) reckons that economic and institutional conditions sustain slavery as a business practice. Despite its illegality and illegitimacy, the practice of forced labor is profitable (Busse \& Braun, 2003), and organizations are able to isolate themselves from external pressures. Still within this scope, there are studies on labor rights for women, human trafficking and the results of the implementation of the International Labor Organization (ILO) as a global initiative to eradicate forced labor (Duplessis, 2004).

Finally, this cluster includes studies which infer that globalization reinforces social inequalities rooted in the historical legacy of slavery and that this legacy affects a minority group, with less voice and influence (Burity, 2008; Maul, 2016).

\section{Cluster 6: The role of accounting in the 19th- century slavery system}

Comprising nine articles, cluster 6 discusses how accounting was used in antebellum US and in the British West Indies. Aspects such as the influence of accounting on the maintenance of slavery, control of the work of slaves and the evaluation of slaves as accounting assets were also found in the documents analyzed (Fleischman, 2004). Accounting also served as an instrument for maintaining slavery in plantations in northern US (Hollister \& Schultz, 2010). It is worth highlighting the publications discussing the critical and ethical perspectives of accounting and its fundamental role in the transition from forced to wage labor (Oldroyd, Fleischman, \& Tyson, 2008). 


\section{Cluster 7: The practice of slavery in the ancient and modern worlds}

In cluster 7, we find six articles and two books. Here, studies cover the practice of slavery in the ancient and modern worlds. Ruef and Harness (2009) analyze the distinction between "modern" and "pre-modern" management thought. Another theme found in this cluster is organization history. Studies argue that it should focus on larger issues concerning management theory by integrating the historical dynamics that affect smaller entrepreneurs and traditionally marginalized groups (Godfrey et al., 2016). There are also discussions about social organizations that influence the improvement of labor relations, such as unions (Anner, 2007), and how Central and South America dealt with the new challenges of labor activities and unionization.

\section{Cluster 8: Rupturing relations with the dark side of history and dealing with its vestiges}

The eighth cluster contains four articles and one book chapter. This cluster discusses cultural elements represented by the remaining memories of slavery. For instance, Lynch and Alberti (2010) discuss the vestiges of institutional racism in race-related cultural exhibitions. Another aspect of cultural-related issues is Brown's (2013) article that analyzes the complexity of the sales operations of museums located in areas related to slave trade. Finally, the celebration of the memory of ancestors is one characteristic of the festivities presently promoted by the black community as a symbol of rupture (Picard, 2006). The cluster also includes studies on Law (self-enforcement) and turnaround management.

\section{Cluster 9: Corporate culture as a form of domination}

Cluster 9 comprises four articles, which have as a common line of thought elements related to corporate culturalism. Fleming (2013) and Willmott $(2003 ; 2013)$ defend that organizational culture and culture management present traces of totalitarianism, therefore are tools to make workers follow organizational goals and values to the detriment of their own. Corporate social responsibility policies in postcolonial African countries can be discriminatory and discretionary, which causes them to perpetuate a colonialist strategy.

\section{DISCUSSION}

As intended, the science mapping provided results that were useful to answer the research questions proposed for this paper.

What is the intellectual structure of recent publications on slavery in the business research area? Results of the bibliographic method of cluster analysis identified nine clusters within slavery-related publications, and these clusters can be referred to as pillars. As we analyze these nine pillars, it is possible to deduce that the theme of slavery is relevant and has been addressed in different forms. Another interesting result is that the practice of slavery has not only lingered in modern organizations, but it has also spread among several levels of management and international businesses. The content of the studies analyzed also show that minorities and underprivileged groups are more exposed to human trafficking, forced labor in sex commerce and labor discrimination. The pillar of contemporary slavery and the legacy of slavery demonstrates that the issue is so flagrant that it has prompted international organizations to create specific initiatives, such as the ILO Declaration on Fundamental Principles and Rights at Work and the efforts sponsored by the United Nations. Finally, it is important to emphasize that the intellectual structure of publications suggests the increasing interest in slavery heritage tourism in countries affected by the slavery system that endured until the 19th century.

How is the past of slavery remembered (or forgotten this century's researches on business research area? Results suggest that studies on slavery and other related topics have gained interest in recent years. By analyzing the results, we can conclude that such an interest is relevant in different areas of management research, such as management history, critical accounting history, supply chain, tourism, and organization studies. However, as argued in previous studies, the legacy of slavery in management practices still lacks attention: there is a need for more studies that evidence the role of the slavery system in 
modern management and in the development of the role of managers. In fact, a pillar of the intellectual structure discusses the concept of organizational culture as a form of domination in modern management. Another aspect that is worth reporting is that most studies present a qualitative or theoretical approach, which denotes an opportunity for discussion: Is a qualitative approach more appropriate for this type of theme or is there room for quantitative studies which have not yet been explored?

\section{CONCLUSION}

This paper aimed to identify and analyze the intellectual structure of publications on slavery in the management research area. To accomplish this goal, we conducted a science mapping of slavery-related publications. Results indicate that the intellectual structure can be grouped into nine pillars, namely, conflicting narratives of slavery in heritage tourism; slavery, heritage tourism and collective memory; slavery and the history of Social Sciences and Humanities; contemporary slavery and other residues of slavery in management practices; the legacy of slavery in social issues of today's globalized world; the role of accounting in the 19th-century slavery system; the practice of slavery in the ancient and modern worlds; rupturing relations with the dark side of history and dealing with its vestiges; and corporate culture as a form of domination.

Although we believe that the methodological approach adopted in this research allowed us to perform an objective analysis, we see the need for adjustments in the bibliographic data as a limitation. Besides, since we used an international database, we could not analyze Brazilian publications. In fact, analyzing the repressed memory of Brazilian slavery (Santos, 2008) in the context of management is necessary and a great opportunity for future research. It is undeniable that slavery is a part of history that cannot be overlooked.

\section{REFERENCES}

Adanhounme, A. B. (2011). Corporate social responsibility in postcolonial Africa: Another civilizing mission? Journal of Change Management, 11(1), 91-110.

Alderman, D. H., Butler, D. L., \& Hanna, S. P. (2015). Memory, slavery, and plantation museums: The River Road Project. Journal of Heritage Tourism, 11(3), 209-218.

Alderman, D. H., \& Gentry, G. W. (2011). Tour guides as creators of empathy: The role of affective inequality in marginalizing the enslaved at plantation house museums. Tourist Studies, 11(1), 3-19.

Alderman, D. H., \& Modlin Jr., A. (2008). (In)Visibility of the enslaved within online plantation tourism marketing: A textual analysis of North Carolina websites. Journal of Travel \& Tourism Marketing, 25(3-4), 265-281.

Alderman, D. H., \& Modlin Jr., A. (2015). On the political utterances of plantation tourists: Vocalizing the memory of slavery on River Road. Journal of Heritage Tourism, 11(3), 275-289.

Anner, M. (2007). Forging New Labor Activism in Global Commodity Chains in Latin America. International Labor and Working-Class History, 72(Fall), 18-41.

Armstrong, C. (2018). The Material Atlantic: Clothing, Commerce, and Colonization in the Atlantic World, 1650-1800. The English Historical Review, 133(563), 962-963.

Bair, A. P. (2007). Prison labor in the United States: An economic analysis. New York: Routledge.

Barlev, B. (2006). A Biblical statement of accountability. Accounting History, 11(2), 173-197.

Beech, J. (2000). The enigma of holocaust sites as tourist attractions - the case of Buchenwald. Managing Leisure, 5(1), 29-41.

Beech, J. G. (2001). The marketing of slavery heritage in the United Kingdom. International 
Journal of Hospitality \& Tourism Administration, 2(3-4), 85-106.

Bright, C. F., \& Butler, D. L. (2015). Webwashing the tourism plantation: Using historic websites to view changes in the representation of slavery at tourism plantations. In S. P. Hanna, A. E. Potter, A. Modlin Jr., P. Carter, \& D. L. Butler (Eds.), Social Memory and Heritage Tourism Methodologies (pp. 31-47). New York: Routledge.

Brown, J. (2013). Dark tourism shops: Selling "dark" and "difficult" products. International Journal of Culture, Tourism, and Hospitality Research, 7(3), 272-280.

Brown, M. T. (2010). Civilizing the economy: A new economics of provision (1st ed.). Cambridge: Cambridge University Press.

Burity, J. A. (2008). Brazil's rise: Inequality, culture and globalization. Futures, 40, 735-747.

Busse, M., \& Braun, S. (2003). Trade and investment effects of forced labour: An empirical assessment. International Labour Review, 142(1), 49-70.

Buzinde, C. N. (2010). Discursive constructions of the plantation past within a travel guidebook. Journal of Heritage Tourism, 5(3), 219-235.

Buzinde, C. N., \& Santos, C. A. (2008). Representations of slavery. Annals of Tourism Research, 35(2), 469-488.

Buzinde, C. N., \& Santos, C. A. (2009). Interpreting slavery tourism. Annals of Tourism Research, 36(3), 439-458.

Campo, S., Mastin, T., \& Frazer, M. S. (2004). Predicting and Explaining Public Opinion Regarding U.S. Slavery Reparations. Howard Journal of Communications, 15(2), 115-130.

Carter, P. L. (2016). Where are the enslaved?: Tripadvisor and the narrative landscapes of southern plantation museums. Journal of Heritage Tourism, 11(3), 235-249.
Cooke, B. (2003). The denial of slavery in management studies. Journal of Management Studies, 40(8), 1895-1918.

Crane, A. (2013). Modern Slavery as a Management Practice: Exploring the Conditions and Capabilities for Human Exploitation. Academy of Management Review, 38(1), 49-69.

Cremaschi, S. (2014). Utilitarianism and malthus' virtue ethics: Respectable, virtuous and happy. Oxford: Routledge.

Dahan, N. M., \& Gittens, M. (2010). Business and the Public Affairs of Slavery: A Discursive Approach of an Ethical Public Issue. Journal of Business Ethics, 92, 227-249.

Dann, G. M. S., \& Potter, R. B. (2008). Supplanting the planters: Hawking heritage in barbados. International Journal of Hospitality \& Tourism Administration, 2(3), 51-84.

Dann, G. M. S., \& Seaton, A. V. (2001). Slavery, Contested Heritage and Thanatourism. International Journal of Hospitality \& Tourism Administration, 2(3-4), 1-29.

de la Fuente, A. (2010). From slaves to citizens? Tannenbaum and the debates on slavery, emancipation, and race eelations in Latin America. International Labor and Working-Class History, 77(Spring), 154-173.

Dolan, C. S. (2005). Fields of obligation: Rooting ethical sourcing in Kenyan horticulture. Journal of Consumer Culture, 5(3), 365-389.

Duplessis, I. (2004). La déclaration de I' OIT relative aux droits fondamentaux au travail [The ILO declaration on fundamental principles and rights at work: A new and more efficient form of regulation?]. Relations Industrielles, 59(1), 52-72.

DuPlessis, R. S. (2016). The Material Atlantic: Clothing, Commerce, and Colonization in the Atlantic World, 1650-1800. Cambridge: Cambridge University Press.

Dwyer, O., Butler, D., \& Carter, P. (2013). Commemorative surrogation and the American 
South's changing heritage landscape. Tourism Geographies: An International Journal of Tourism Space, Place and Environment, 15(3), 424-443.

Engerman, S. (2011). Slavery, freedom, and Sen. Feminist Economics, 9(2-3), 185-211.

Essah, P. (2008). Slavery, Heritage and Tourism in Ghana. International Journal of Hospitality \& Tourism Administration, 2(3-4), 31-49.

Fleischman, R. K. (2004). Confronting moral issues from accounting's dark side. Accounting History, 9(1), 7-23.

Fleischman, R. K., Oldroyd, D., \& Tyson, T. N. (2004). Monetising human life: Slave valuations on US and British West Indian plantations. Accounting History, 9(2), 37-62.

Fleischman, R. K., Oldroyd, D., \& Tyson, T. N. (2011). The efficacy/inefficacy of accounting in controlling labour during the transition from slavery in the United States and British West Indies. Accounting, Auditing \& Accountability Journal, 24(6), 751-780.

Fleischman, R. K., \& Tyson, T. N. (2002). The interface of race and accounting: A reply to burrows. Accounting History, 7(1), 115-122.

Fleischman, R. K., \& Tyson, T. N. (2004). Accounting in service to racism: monetizing slave property in the antebellum South. Critical Perspectives on Accounting, 15(3), 376-399.

Fleming, P. (2013). 'Down with Big Brother!' The End of 'Corporate Culturalism'? Journal of Management Studies, 50(3), 474-495.

Freedman, C. (2008). Chicago fundamentalism: Ideology and methodology in economics (World Scie). Singarore.

Frost, W. (2004). Heritage tourism on Australia's Asian shore: A case study of Pearl Luggers, Broome. Journal of Tourism Research, 9(3), 281-291.

Gaido, D. (2006). The Formative Period of American Capitalism: A Materialist Interpretation. London: Routledge.
Gijanto, L. A. (2011). Competing narratives: Tensions between diaspora tourism and the Atlantic past in the Gambia. Journal of Heritage Tourism, 6(3), 227-243.

Giovannetti, J. L. (2009). Subverting the master's narrative: Public histories of slavery in plantation America. International Labor and Working-Class History, 76(Fall), 105-126.

Giusta, M. Della, Tommaso, M. Di, \& Strøm, S. (2008). Sex Markets: A Denied Industry (1st ed.). London: Routledge.

Godfrey, P. C., Hassard, J., O'Connor, E. S., Rowlinson, M., \& Ruef, M. (2016). What is organizational history? Toward a creative synthesis of history and organization studies. Academy of Management Review, 41(4), 590-608.

Gold, S., Trautrims, A., \& Trodd, Z. (2015). Modern slavery challenges to supply chain management. Supply Chain Management: An International Journal, 20(5), 485-494.

Goldin, C. (2016). Human Capital. In C. Diebolt \& M. Haupert (Eds.), Handbook of Cliometrics. New York: Springer Reference.

Haley, A. (1976). Roots: the saga of an American family. USA: Doubleday.

Hanna, S. P. (2015). Placing the enslaved at Oak Alley Plantation: Narratives, spatial contexts, and the limits of surrogation. Journal of Heritage Tourism, 11(3), 219-234.

Hayek, M., Novicevic, M. M., Humphreys, J. H., \& Jones, N. (2010). Ending the denial of slavery in management history Paternalistic leadership of Joseph Emory Davis. Journal of Management History, 16(3), 367-379.

Hollister, J., \& Schultz, S. M. (2010). Slavery and emancipation in rural New York: Evidence from nineteenth-century accounting records. Accounting History, 15(3), 371-405.

Jakobsson, N., \& Kotsadam, A. (2013). The law and economics of international sex slavery: Prostitution laws and trafficking for sexual 
exploitation. European Journal of Law and Economics, 35, 87-107.

Jones, N., Novicevic, M. M., Hayek, M., \& Humphreys, J. H. (2012). The first documents of emancipated African American management: The letters of Benjamin Montgomery. Journal of Management History, 18(1), 46-60.

Kong, T. S. K. (2006). What It Feels Like for a Whore: The Body Politics of Women Performing Erotic Labour in Hong Kong. Gender, Work \& Organization, 13(5), 409-434.

Litvin, S. W., \& Brewer, J. D. (2016). Charleston, South Carolina Tourism and the presentation of urban slavery in an historic Southern city. Journal of Hospitality \& Tourism Administration, 9(1), 71-84.

Lohrke, F. T., Ahlstrom, D., \& Bruton, G. D. (2012). Extending Turnaround Process Research: Important Lessons From the U.S. Civil War. Journal of Management Inquiry, 21(2), 217-234.

Lynch, B. T., \& Alberti, S. J. M. M. (2010). Legacies of prejudice: Racism, co-production and radical trust in the museum. Museum Management and Curatorship, 25(1), 13-25.

Ma, Y. J., Lee, H., \& Goerlitz, K. (2015). Transparency of Global Apparel Supply Chains: Quantitative Analysis of Corporate Disclosures. Corporate Social Responsibility and Environmental Management, 23(5), 308-318.

Macintosh, N. B. (2009). "Effective" genealogical history: Possibilities for critical accounting history research. Accounting Historians Journal, 36(1), 127.

Magnan, G. M., Fawcett, S. E., \& Alcantar, T. N. (2011). On supply chains and reputation risk: Tracking changes in supplier codes of conduct Kenneth Henshaw. International Journal of Procurement Management, 4(6), 567-588.

Maul, D. R. (2016). The International Labour Organization and the struggle against forced labour from 1919 to the present. Labor History, 48(4), 477500.
Mcdade, K. (2011). Liverpool slave merchant entrepreneurial networks, 1725- 1807. Business History, 53(7), 1092-1109.

Mittal, S., \& Weingast, B. R. (2011). Selfenforcing constitutions: With an application to democratic stability in America's first century. Journal of Law, Economics, and Organization, 29(2), 278-302.

Mowatt, R. A., \& Chancellor, C. H. (2011). Visiting death and life. Dark tourism and slave castles. Annals of Tourism Research, 38(4), 1410-1434.

Neumayer, E., \& Soysa, I. de. (2007). Globalisation, Women's Economic Rights and Forced Labour. World Economy, 30(10), 15101535.

New, S. J. (2015). Modern slavery and the supply chain: the limits of corporate social responsibility? Supply Chain Management: An International Journal, 20(6), 687-707.

Nosella, A., \& Cantarello, S. (2012). The intellectual structure of organizational ambidexterity: A bibliographic investigation into the state of the art. Strategic Organization, 10(4), 450-465.

Oldroyd, D., Fleischman, R. K., \& Tyson, T. N. (2008). The culpability of accounting practice in promoting slavery in the British Empire and antebellum United State. Critical Perspectives on Accounting, 19(5), 764-784.

Orwell, G. (2011). George Orwell: A Life in Letters. London: Penguin.

Osterhammel, J. (2014). The Transformation of the World: A Global History of the Nineteenth Century. Princeton: Princeton University Press.

Pennington, J. R., Ball, A. D., Hampton, R. D., \& Soulakova, J. N. (2009). The Cross-National Market in Human Beings. Journal of Macromarketing, 29, 119-134.

Perrow, C. (2009). Organizing America: Wealth, power, and the origins of corporate capitalism. Princeton: Princeton University Press. 
Phillips Jr., W. D. (2013). Slavery in Medieval and Early Modern Iberia. Philadelphia: University of Pennsylvania Press.

Picard, D. (2006). Gardening the past and being in the world: A popular celebration of the abolition of slavery in la réunion. In D. Picard \& M. Robinson (Eds.), Festivals, Tourism and Social Change: Remaking Worlds. Bristol: Channel View Publications.

Podoshen, J. S. (2012). The African American consumer revisited: Brand loyalty, word-of-mouth and the effects of the black experience. Journal of Consumer Marketing, 25(4), 211-222.

Potter, A. E. (2016). "She goes into character as the lady of the house": Tour guides, performance, and the Southern plantation performance, and the Southern plantation. Journal of Heritage Tourism, 11(3), 250-261.

Quevedo-Silva, F., Santos, E. B., Brandão, M. M., \& Vils, L. (2016). Estudo bibliométrico: orientações sobre sua aplicação. Revista Brasileira de Marketing - Remark[Brazilian Journal of Marketing], 15(2), 246-262.

Quirk, J. (2006). The Anti-Slavery Project: Linking the Historical and Contemporary. Human Rights Quarterly, 28(3), 565-598.

Robinson, J. (2002). Race, Gender, and Familial Status: Discrimination in One US Mortgage Lending Market. Feminist Economics, 8(2), 63-85.

Rodet, M. (2014). Forced Labor, Resistance, and Masculinities in Kayes, French Sudan, 1919-1946. International Labor and Working-Class History, 86(fall), 107-123.

Ruef, M. (2014). Between Slavery and Capitalism: The Legacy of Emancipation in the American South. Princeton University Press.

Ruef, M., \& Harness, A. (2009). Agrarian origins of management ideology: The Roman and antebellum cases. Organization Studies, 30(6), 589607.
Santos, M. S. dos. (2008). The repressed memory of Brazilian slavery. International Journal of Cultural Studies, 11(2), 157-175.

Schermerhorn, C. (2015). The Business of Slavery and the Rise of American Capitalism, 1815-1860. London: Yale University Press.

Seaton, A. V. (2001). Sources of slavery destinations of slavery: The silences and disclosures of slavery heritage in the UK and US. International Journal of Hospitality \& Tourism Administration, 2(3-4), 107-129.

Shafique, M. (2013). Thinking inside the box? Intellectual structure of the knowledge base of innovation research (1998 - 2008). Strategic Management Journal, 34, 62-93.

Small, S. (2013). Still back of the big house: Slave cabins and slavery in Southern heritage tourism. Tourism Geographies: An International Journal of Tourism Space, Place and Environment, 15(3), 405423.

Teye, V. B., \& Timothy, D. J. (2004). The varied colors of slave heritage in West Africa white American stakeholders. Space \& Culture, 7(2), 145155.

Tyson, T. N., Oldroyd, D., \& Fleischman, R. K. (2005). Accounting, coercion and social control during apprenticeship: Converting slave workers to wage workers in the British west Indies, C.18341838. Accounting Historians Journal, 32(2), 201231.

Van Eck, N. J., \& Waltman, L. (2014). Visualizing bibliometric networks. In Y. Ding, R. Rousseau, \& D. Wolfram (Eds.), Measuring scholarly impact: Methods and practice (pp. 285-320). Springer.

Vollmers, G. (2003). Industrial slavery in the United States: The North Carolina turpentine industry 1849-61. Accounting, Business \& Financial History, 13(3), 369-292.

Wanderley, S., \& Barros, A. (2018). Decoloniality, geopolitics of knowledge and historic turn: towards a Latin American agenda. Management \& Organizational History, 14(1), 79-97. 
Weissbrodt, D. (2002). Abolishing slavery and its contemporary forms. Anti-Slavery International. New York: Office of the United Nations High Commissioner for Human Rights.

Willmott, H. (1993). Strength is ignorance; slavery is freedom: Managing culture in modern organizations. Journal of Management Studies, 30(4), 515-552.

Willmott, H. (2003). Renewing Strength: Corporate Culture Revisited. Management, 6, 7387.

Willmott, H. C. (2013). 'The Substitution of One Piece of Nonsense for Another': Reflections on Resistance, Gaming, and Subjugation. Journal of Management Studies, 50(3), 443-473.

Winter, S., \& Lasch, R. (2016). Environmental and Social Criteria in Supplier Evaluation - Lessons from the Fashion and Apparel Industry. Journal of Cleaner Production, 15, 175-190.

Yankholmes, A., \& Akyeampong, O. A. (2010). Tourists' perceptions of heritage tourism development in Danish-Osu, Ghana. International Journal of Tourism Research, 12(5), 603-616.

Yankholmes, A., \& Mckercher, B. (2015a). Rethinking slavery heritage tourism. Journal of Heritage Tourism, 10(3), 233-247.

Yankholmes, A., \& Mckercher, B. (2015b). Understanding visitors to slavery heritage sites in Ghana. Tourism Management, 51, 22-32.

Zupic, I., \& Čater, T. (2015). Bibliometric methods in management and organization. Organizational Research Methods, 18(3), 429-472. 